\title{
The involvement of miR-100 in bladder urothelial carcinogenesis changing the expression levels of mRNA and proteins of genes related to cell proliferation, survival, apoptosis and chromosomal stability
}

Denis R Morais ${ }^{1,2^{*}}$, Sabrina T Reis ${ }^{1}$, Nayara Viana', Camila Berfort Piantino ${ }^{1}$, Cristina Massoco², Caio Moura', Nelson Dip ${ }^{1}$, Iran A Silva ${ }^{1}$, Miguel Srougi ${ }^{1}$ and Katia RM Leite ${ }^{1}$

\begin{abstract}
Introduction: MicroRNAs (miRNA) are small non-coding RNAs that play an important role in the control of gene expression by inhibiting protein translation or promoting messenger RNA degradation. Today, miRNAs have been shown to be involved in various physiological and pathological cellular processes, including cancer, where they can act as oncogenes or tumor suppressor genes. Recently, lowered expression of miR-100, resulting in upregulation of FGFR3, has been correlated with low-grade, non-invasive bladder urothelial cancer, as an alternative oncogenesis pathway to the typical FGFR3 gene mutation. Our aim is to analyze the role of miR-100 in bladder cancer cell lines in controlling the expression of some of its possible target genes, including FGFR3 and its relationship with proliferation, apoptosis and DNA ploidy.
\end{abstract}

Methods: The bladder cancer cell lines RT4 and T24 were transfected with pre-miR 100, anti-miR 100 and their respective controls using a lipid-based formulation. After transfection mRNA and protein levels of its supposed target genes THAP2, BAZ2A, mTOR, SMARCA5 and FGFR3 were analyzed by quantitative real time polymerase chain reaction (qRT-PCR) and western blotting. Cell proliferation, apoptosis and DNA ploidy were analyzed by flow cytometry. For statistical analysis, a t-test was applied, $p<0.05$ was considered significant.

Results: After miR-100 transfection, there was a significant reduction in the mRNA of mTOR $(p=0.006)$, SMARCA5 $(p=0.007)$ and BAZ2A $(p=0.029)$ in RT4, mTOR $(p=0.023)$ and SMARCA5 $(p=0.015)$ in T24. There was a reduction in the expression of all proteins, variable from $22.5 \%$ to $57.1 \%$ in both cell lines. In T24 miR-100 promoted an increase in cell proliferation and anti-miR 100 promoted apoptosis characterizing miR-100 as an oncomiR in this cell line representative of a high-grade urothelial carcinoma.

Conclusion: miR-100 transfection reduces expression of BAZ2A, mTOR and SMARCA5 mRNA and protein in BC cell lines. miR-100 would be classified as an oncomiR in T24 cells representative of high grade urothelial carcinoma promoting increase in cell proliferation and reduction in apoptosis. The knowledge of miRNA role in tumors will allow their use as tumor markers and targets for new therapies.

Keywords: Bladder cancer, MicroRNA, miR-100, Gene expression, Protein expression, PCR, Western blotting

\footnotetext{
* Correspondence: denisreis_morais@yahoo.com.br

'Laboratory of Medical Research, Department of Urology - LIM55, University of Sao Paulo Medical School, Sao Paulo, Brazil

${ }^{2}$ Department of Pathology, University of Sao Paulo Veterinary Medicine and Zootechnics School, Sao Paulo, Brazil
}

\section{() Biomed Central}

(c) 2014 Morais et al.; licensee BioMed Central Ltd. This is an Open Access article distributed under the terms of the Creative Commons Attribution License (http://creativecommons.org/licenses/by/4.0), which permits unrestricted use, distribution, and reproduction in any medium, provided the original work is properly credited. The Creative Commons Public Domain Dedication waiver (http://creativecommons.org/publicdomain/zero/1.0/) applies to the data made available in this article, unless otherwise stated. 


\section{Introduction}

MicroRNAs (miRNAs) are a class of small non-coding RNAs, approximately 19 to 22 nucleotides in length that are important in the regulation of gene expression [1]. At present, approximately 1,600 human miRNAs have been identified by sequence analysis (miRBase) [2], and it is believed that miRNAs regulate approximately $30 \%$ of all human genes [3]. Aberrant expression patterns and functional abnormalities of miRNAs are implicated in several human diseases, including cancer [4]. They play important roles in the regulation of cellular processes, such as proliferation, apoptosis and differentiation. Recent evidences suggest that miRNAs are context and cell-dependent and behave differently depending on the tumor type or tumor stage [4]. We have recently demonstrated that miR-100 is underexpressed in $100 \%$ of low-grade, non-invasive bladder cancers, with FGFR3 as a putative target gene [5], representing a possible first step of tumorigenesis, before the typical FGFR3 mutation. There are other proposed target genes of miR100 that could be involved in bladder carcinogenesis, such as THAP2, BAZ2A, SMARCA5 and mTOR. Our aim is to study the role of miR-100 in bladder cancer cell lines in controlling the expression of mRNAs and proteins of its putative target genes and its relationship with proliferation, apoptosis and DNA ploidy.

\section{Methods}

\section{Cell culture}

The human bladder cancer cell line RT4 was obtained from the European Collection of Cell Cultures (ECACC) and was cultured in McCoy's medium supplemented with $20 \%$ fetal bovine serum with a $1 \%$ antibiotic/ antimycotic solution (Sigma Co., St. Louis, MO, USA) at $37^{\circ} \mathrm{C}$ in an atmosphere of $5 \% \mathrm{CO}_{2}$. The human bladder cancer cell line T24 was kindly provided by Prof. Daisy Salvadori (Unesp, Botucatu, SP, Brazil) and was maintained as described above.

\section{miR-100 and anti-miR 100 cell transfection}

The cells were seeded in 24-well plates at a concentration of $5.0 \times 10^{4} /$ well for miRNA and anti-miRNA transfection. The reverse-transfections into the bladder cell lines were carried out in Opti-MEM I using cationic liposomes (Lipofectamine 2000; Invitrogen, Carlsbad, CA, USA) according to the manufacturer's protocol. Synthetic miR-100 (Catalog number AM17100 Assay ID PM 10188), anti-miR 100 (Catalog number AM17000 - Assay ID AM 10188) and their respective scrambled controls, control miR (ctrl miR; catalog number AM17110) and control anti-miR (ctrl $\alpha \mathrm{miR}$; catalog number AM17010), were purchased from Ambion (Austin, TX, USA). The negative controls and the miRNAs were used at a final concentration of $50 \mathrm{nM}$.

\section{RNA extraction and quantitative real-time PCR (qRT-PCR)}

The RNA extraction was performed using the mirVana kit (Ambion, Austin, TX, USA) according to the manufacturer's instructions. RNA concentrations were determined by $260 / 280 \mathrm{~nm}$ absorbance using a Nanodrop ${ }^{\circ}$ ND-1000 spectrophotometer (Thermo Scientific). For cDNA synthesis, $200 \mathrm{ng}$ of total RNA was reverse transcribed using random primers and Multiscribe reverse transcriptase (Applied Biosystems, Foster City, CA, USA) with incubation at $25^{\circ} \mathrm{C}$ for $10 \mathrm{~min}$, followed by $37^{\circ} \mathrm{C}$ for $120 \mathrm{~min}$ and $85^{\circ} \mathrm{C}$ for $5 \mathrm{~min}$. To determine the expression of the mRNAs for THAP2, BAZ2A, mTOR, SMARCA5 and FGFR3, qRT-PCR was performed using TaqMan assays from Applied Biosystems (Foster City, CA, USA). All samples were amplified in a 7500 fast real-time PCR system (Applied Biosystems, Foster City, CA, USA). The samples were processed at $50^{\circ} \mathrm{C}$ for 2 min, followed by $95^{\circ} \mathrm{C}$ for $10 \mathrm{~min}$ and 40 thermal cycles of $95^{\circ} \mathrm{C}$ for 15 seconds and $60^{\circ} \mathrm{C}$ for $1 \mathrm{~min}$. The reactions were conducted in duplicate, and human $ß 2$ microglobulin was used as an internal endogenous control. The relative expression level of the mRNAs was calculated by the $2^{-\Delta \Delta C t}$ method. The data shown are representative of three independent experiments.

\section{Western blotting}

For western blotting, T24 and RT4 cells $\left(2,5 \times 10^{5}\right.$ cells/ well) were transfected with $50 \mathrm{nM}$ of pre-miR 100 , antimiR 100, or their respective controls. After $48 \mathrm{~h}$, the cells were resuspended and lysed in their wells using RIPA buffer and protease inhibitor (Millipore, Billerica, MA, USA). Protein concentrations were established using the Pierce $660 \mathrm{~nm}$ Protein Assay (Thermo Scientific). From the cell lysate, $30 \mu \mathrm{g}$ of protein was electrophoresed on a $12 \%$ SDS-polyacrylamide gel. After electrophoresis, the protein was transferred to a PVDF Immobilon-P membrane (Millipore, Billerica, MA, USA). The membrane was blocked in Tris-buffered saline (TBS) containing 1\% BSA (bovine serum albumin) (Sigma, St. Louis, MO, USA) and $1 \%$ Tween-20 for $15 \mathrm{sec}$ at room temperature. The 20-min primary antibody incubation occurred in a SNAP camera (Millipore) following the manufacturer's instructions. The primary antibodies used were: mTOR (Abcam 1:500), FGFR3 (Abcam 1:600), SMARCA5 (Abcam 1:2000), BAZ2A (Abcam 1:500) and THAP2 (Proteintech 1:600). $\beta$-actin (Millipore 1:500) was used as a control. The secondary antibody was used at a 1:5000 dilution with an incubation time of $20 \mathrm{~min}$ (Millipore) in the same equipment. Protein expression analysis was performed using Alliance 4.7 equipment (Uvitec, Cambridge, UK) running the software package Alliance 16.06. 


\section{Analysis of DNA ploidy, cell cycle and apoptosis by flow cytometry}

For analysis of DNA ploidy, cell cycle and apoptosis the cells T24 and RT4 were transfected with pre-miR 100, anti-miR 100 and their respective controls as described above, and after 96 hours of transfection, cells were fixed in $70 \%$ ethanol, stained with propidium iodide (PI) diluted in PBS $(200 \mu \mathrm{g} / \mathrm{ml}$, RNAse A $20 \mathrm{mg} / \mathrm{ml}$, triton $\mathrm{X}-100$ and $\mathrm{PBS} \mathrm{pH} 7.4$ ) for $15 \mathrm{~min}$ at $37^{\circ} \mathrm{C}$. The apoptosis was measured using the Annexin V Apoptosis Detection Kit I (BD Biosciences, USA) according the instructions of the manufacturer's. RT4 and T24 cells $\left(1 \times 10^{5}\right.$ cells per well $)$ were seeded in a 12 -well plate and after 96 hours of transfection they were harvested and stained with annexin-V-FITC and PI. The analyses of DNA ploidy, cell cycle and apoptosis were performed using the FlowJo (Tree Star) version 10 and FlowJo version 7.6.1 (Three Star). The results were expressed as mean \pm SEM.

\section{Statistical analysis}

For statistical analysis, experiments were performed in triplicate. With GraphPad Prism version 5 software Student's $t$-test was used to calculate the difference in expression of target genes, cell proliferation and apoptosis, and $\mathrm{p}<0.05$ was considered significant.

\section{Results}

RT4 cells exposed to pre-miR 100 showed a significant reduction in mRNA expression of $\operatorname{mTOR}(53 \%, \mathrm{p}=0.006)$, SMARCA5 (69.6\%, $\mathrm{p}=0.007)$ and BAZ2A (53\%, $\mathrm{p}=0.029)$. THAP2 reduction could be considered marginal $(31.4 \%$, $\mathrm{p}=0.053$ ). FGFR3 mRNA expression decreased 20.6\% but did not reach statistical significance compared to the control $(\mathrm{p}=0.28)$. When exposed to anti-miR 100, we observed an increase in the expression of all genes, but the increase was significant only for THAP2 and BAZ2A, with increases of $23.8 \%(p=0.03)$ and $32 \%(p=0.004)$, respectively (Figure 1).

T24 cells showed a significant reduction in the expression of mTOR (30.7\%, p = 0.02) and SMARCA5 (39.2\%, $\mathrm{p}=0.01$ ) after exposure to pre-miR 100. The other four genes also showed decreased, but non-significant, expression relative to the controls. When exposed to antimiR 100, all genes except SMARCA5 showed enhanced, but non-significant, expression relative to the controls (Figure 2).

The western blot analysis of the proteins encoded by the genes THAP2, BAZ2A, mTOR, SMARC5 and FGFR3 in RT4 and T24 bladder cancer cells exposed to pre-miR 100 , anti-miR 100 or their respective controls is shown in Figures 3 and 4 . We observed a decrease in protein levels, ranging from $30.8 \%$ to $49.6 \%$ in RT4 cells and $22.5 \%$ to $57.1 \%$ in T24 cells. The largest decreases in expression were observed for SMARCA5 (49.6\%) and FGFR3 (40.5\%) in RT4 cells and mTOR (57.1\%), SMARCA5 (51.7\%) and FGFR3 (46.9\%) in T24 cells.

For RT4 cell line there was no difference in cell proliferation comparing transfected cells with pre-miR 100, anti-miR-100 and their negative controls. In T24 cell line exposed to pre-miR $10044.5 \%$ of the cells were in G2/S or $\mathrm{M}$ versus $36 \%$ in the control. Although this difference was not statistically different $(p=0.37)$, there was an increase of $8.5 \%$ in cell proliferation after miR-100 transfection. There was no differences in the number of cells in apoptosis in both cell lines after miR-100 transfection. However, when T24 cells were exposed to anti-miR 100 there was an increase of $13 \%$ in cells in apoptosis, although this difference was not significant $(\mathrm{p}=0.642)$ (Table 1).

The DNA ploidy is usually expressed as the DNA index (DI), that is, the ratio G0/G1 peak mean fluorescence of the tumor and the G0/G1 peak of the reference diploid ( $2 \mathrm{n})$ population. There was no alteration in DNA ploidy in cell lines RT4 and T24 after transfection of pre-miR 100 and anti-miR 100.

\section{Discussion}

This study investigated the regulation of putative target genes of miR-100 in two bladder urothelial cancer cell lines representatives of low (RT4) and high (T24) grade tumors. After miR-100 transfection, we observed a reduction in mRNA expression of the genes of interest, but the reduction was significant only for $\mathrm{mTOR}, \mathrm{BAZ} 2 \mathrm{~A}$ and SMARCA5. Declines in protein levels were also detected.

The functional significance of miR-100 in cancer biology is supported by recent studies that show change in its expression in several types of cancer. Downregulation of miR-100 has been described in several tumors, such as squamous cell carcinoma of the tongue and oral cavity [6,7], nasopharyngeal cancer [8], hepatocellular carcinoma [9], hepatoblastomas [10] and serous ovarian carcinoma [11]. Overexpression of miR100 has been observed in medulloblastomas [12], and gastric [13], pancreatic [14] and prostate cancers [15].

In bladder urothelial cancer, our group and others have shown that the downregulation of miR-100 is characteristic of low-grade, non-invasive carcinomas and is thought to be an alternative pathway to the FGFR3 mutation typical of this type of tumor $[16,17]$. FGFR3 is a putative target of miR-100 and was previously shown to downregulate the gene expression by Luciferase reporter assay [18]. In our assays, we observed a reduction in FGFR3 mRNA expression of $20.6 \%$ in RT4 cells and $28 \%$ in T24 cells, which was not statistically significant compared to controls. However, there was a reduction in the protein expression by $40.5 \%$ in RT4 cells and $46.9 \%$ in T24 cells, leading us to conclude that miR-100 plays a 

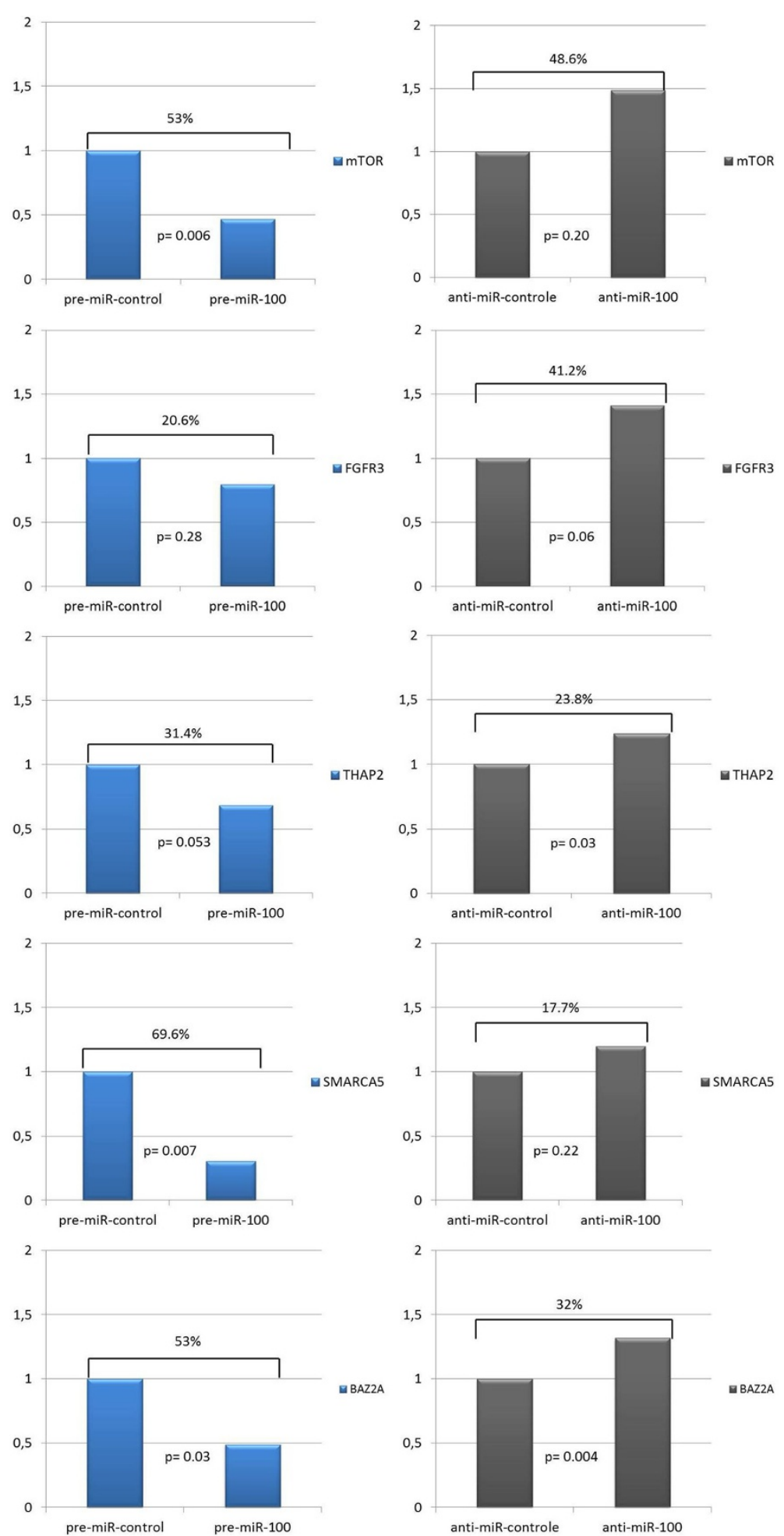

Figure 1 mRNA expression of FGFR3, mTOR, BAZ2A, SMARCA5 and THAP2 after transfection of the RT4 low grade urothelial bladder cancer cell line with miR-100 and anti-miR 100.

role in regulating FGFR3 expression in both low and high grade urothelial carcinomas. FGFR3 mutation is the most common phenomenon in low-grade non-invasive urothelial carcinomas, described in $70 \%$ of the cases and identified as a molecular marker of non-aggressive disease $[19,20]$. Catto was the first to associate miR-100 


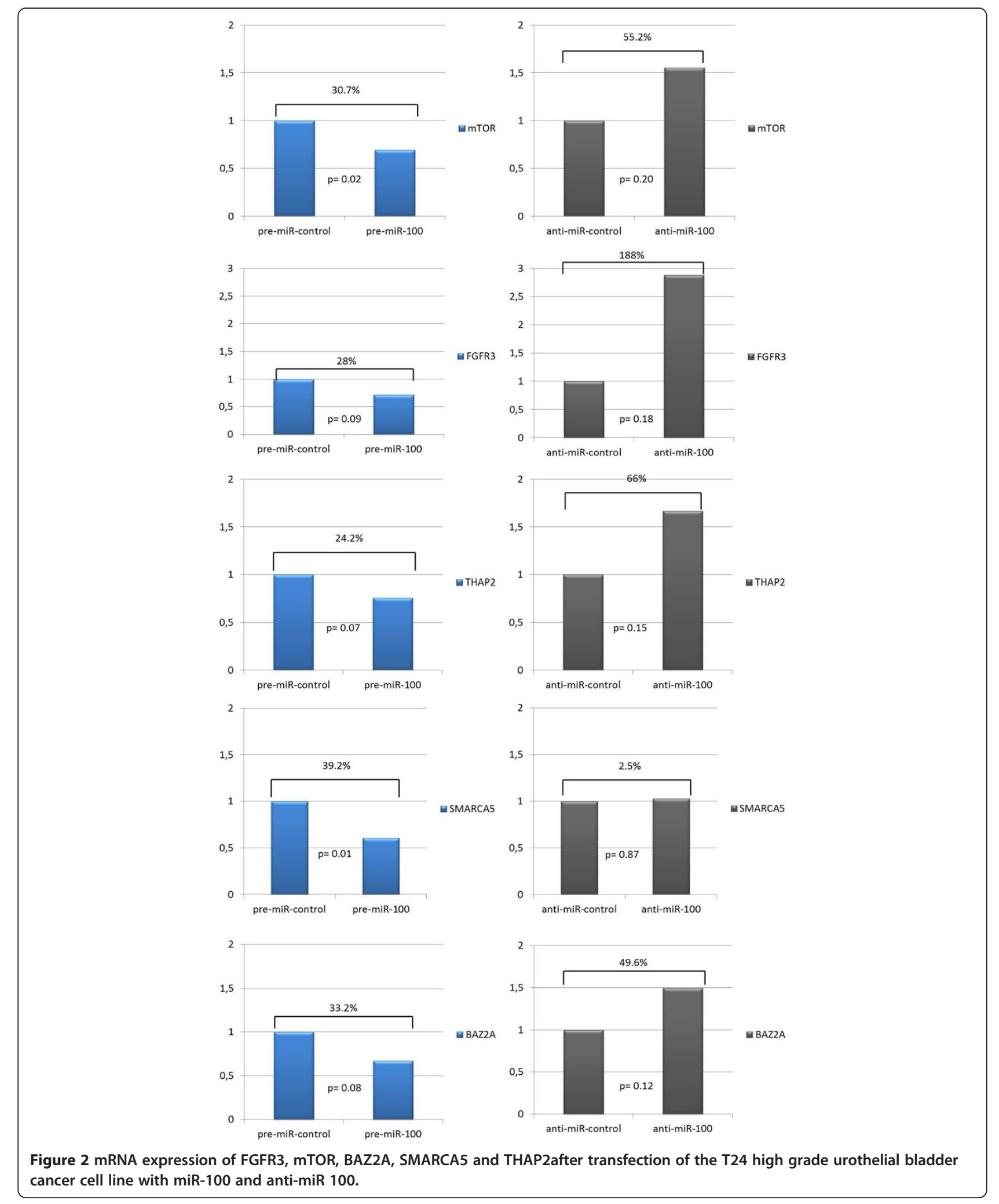

loss and upregulation of FGFR3 in low-grade bladder cancer, proposing that miR-100 loss could precede the FGFR3 mutation [18]. In this context, miR-100 could be considered as a tumor suppressor miRNA because it regulates the activity of the tyrosine kinase receptor FGFR3. 


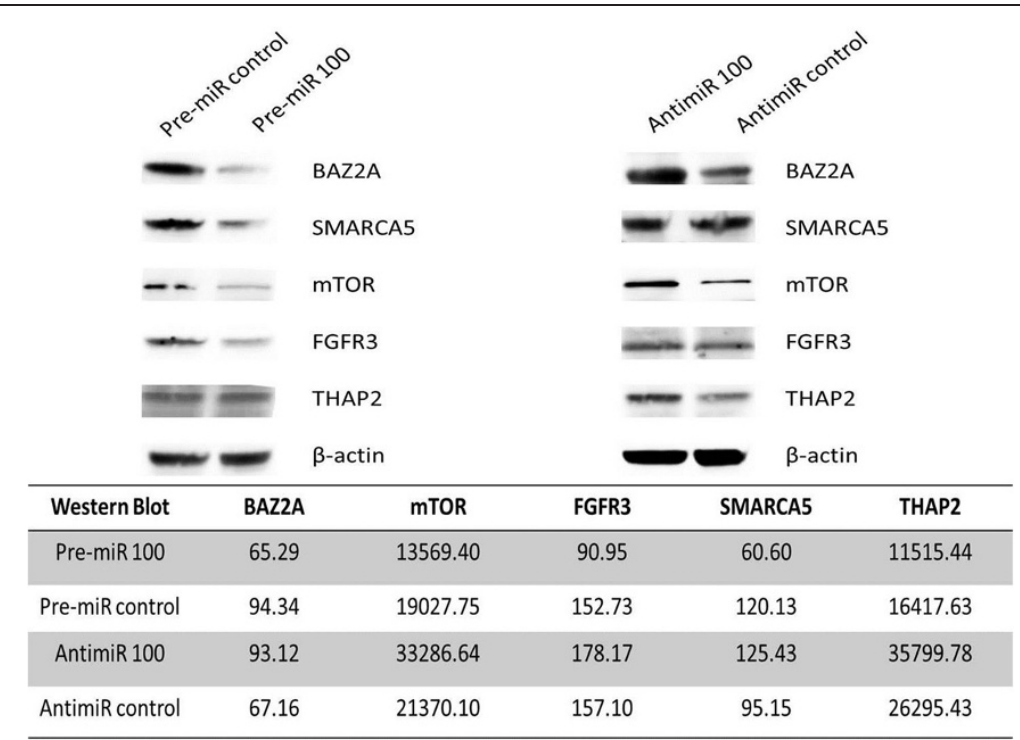

Figure 3 mTOR, FGFR3, THAP2, SMARCA5 and BAZ2A protein expression in RT4 bladder cancer cells, evaluated by western blotting, after exposure to miR-100.

The most affected genes in both types of cells after miR100 transfection were SMARCA5 and mTOR. There was a significant reduction in the expression of both mRNA and protein.

mTOR (mammalian target of rapamycin) is a serinethreonine protein kinase, which acts with PI3K, AKT and the tumor suppressor gene PTEN to form a signaling pathway involved in the regulation of protein synthesis, cell growth, proliferation, survival, apoptosis, and angiogenesis [21]. Deregulation of the mTOR pathway has been related to oncogenesis in several malignancies, including bladder cancer [22]. Our data show that the mTOR gene was downregulated by miR-100 in bladder cancer cell lines. There was a significant reduction in mTOR mRNA expression and a strong reduction of mTOR protein expression in the T24 Cell Line (57.1\%). This result suggests again that miR100 is a tumor suppressor miRNA because it downregulates the important $\mathrm{PI} 3 \mathrm{~K} / \mathrm{AKt} / \mathrm{mTOR}$ pathway. The same result was recently described by $\mathrm{Xu}$ et al., who identified miR-100 as a

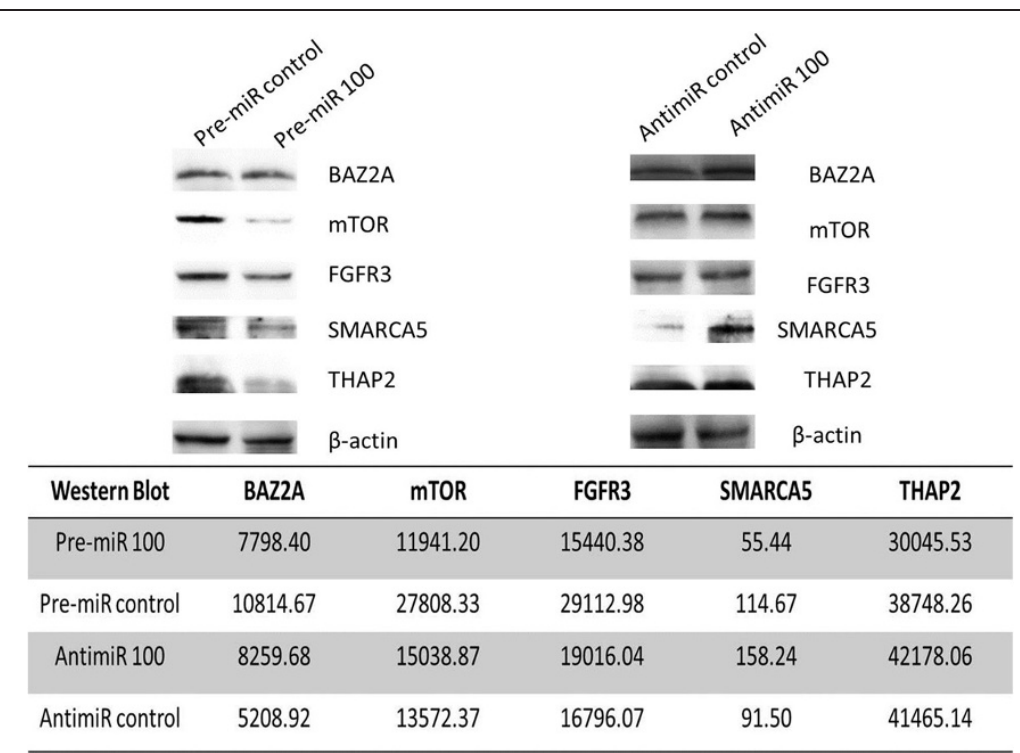

Figure 4 mTOR, FGFR3, THAP2, SMARCA5 and BAZ2A protein expression in T24 bladder cancer cells, evaluated by western blotting, after exposure to miR-100. 
Table 1 Percentage of cells in phases G1, S and G2 / M and apoptosis in RT4 and T24 cell lines examed by flow cytometry

\begin{tabular}{lllll}
\hline & miR-100 & miR-control & Anti-miR-100 & $\begin{array}{l}\text { Anti-miR- } \\
\text { control }\end{array}$ \\
\hline Cell Line RT4 & & & & \\
G1(\%) & 58 & 61 & 58 & 52 \\
S(\%) & 8 & 7 & 8 & 8 \\
G2/M(\%) & 32 & 32 & 34 & 34 \\
Apoptosis(\%) & 57 & 59 & 60.5 & 62 \\
Cell Line T24 & & & & \\
G1(\%) & 56.5 & 64 & 59 & 59 \\
S(\%) & 12.5 & 6 & 8 & 9 \\
G2/M(\%) & 32 & 30 & 33 & 32 \\
Apoptosis(\%) & 62 & 64 & 39 & 26 \\
\hline
\end{tabular}

suppressor of cell growth in human bladder cancer in part at least through repression of mTOR [23].

SMARCA5 (hSNF2H) is a member of the SWI/SNF family involved in both homologous and non-homologous end joining recombination required for efficient DNA repair [24-26]. In this context, miR-100 should act as an oncomiR because the downregulation of SMARCA5 could result in deficiencies in DNA repair that could promote chromosomal instability, a hallmark of high-grade bladder cancer.

Other genes are also putative targets of miR-100 and could be important in the bladder carcinogenesis process. The Thanatos-associated protein (THAP) DNA-binding domain is a conserved $\mathrm{C} 2 \mathrm{CH}$ zinc-finger motif shared by a large family of cellular factors with functions associated with cell-proliferation and cell cycle control. The function of THAP2 is not well known, but THAP1 has been described as an inhibitor of the cell cycle, interfering with $\mathrm{pRb} / \mathrm{E} 2 \mathrm{~F}$ [27]. Others suggest that THAP proteins could play a major role in targeting genes to promote transcription regulation through interactions with protein complexes associated with chromatin remodeling [28]. Another role of THAP2 is associated with apoptosis, which, together with the transcription repressor protein Par-4 (prostate-apoptosis-response-4; a pro-apoptotic factor that suppresses the expression of BCL2, an important inhibitor of apoptosis), facilitates the process of programmed cell death [29]. Therefore, repression of THAP2 by miR-100 could affect apoptosis in urothelial cancer. We detected a $31.4 \%$ reduction in THAP2 mRNA in RT4 cells and a $24.2 \%$ reduction in T24 cells, the reduction in THAP2 protein expression was $29.8 \%$ in RT4 cells and $22.5 \%$ in T24 cells. The T24 cell line is a high-grade urothelial carcinoma, where the loss of function of tumor suppressor genes, such as p53 and Rb, and chromosomal instability are typical. In this context, miR-100 would act as an oncomiR because it downregulates THAP2, a putative tumor suppression protein that is important for $\mathrm{Rb}$ function, apoptosis induction and DNA chromatin remodeling $[27,30,31]$.

In RT4 cells, BAZ2A was lowered after miR-100 transfection. BAZ2A, also known as TIP5 and WALp3, functions with the SWI/SNF family member SNF2h to form the NoRC (nucleolar remodeling complex). This complex induces nucleosome sliding, which is important for transcription regulation [32].

It is reasonable to think that the down expression of miR-100 that we previously observed in low-grade, noninvasive bladder urothelial cancer is related to the lack of control of mTOR and FGFR3 and to the maintenance of genomic stability due to not interfering with SMARCA5. In more aggressive urothelial cancers, miR-100 was related to increase in cell proliferation and its inhibition promoted increase in apoptosis. The decrease in expression of SMARCA5 and BAZ2A that we also identified in this lineage may primarily be influencing chromosomal stability that is a characteristic of this tumor, nevertheless no change occurred after inhibition or transfection of the miRNA. The observation of the behavior in gene and protein expression in human cancer cell lines throughout miRNAs exposure would bring a new knowledge that will permit their use as tumor markers and targets for treatment.

\section{Competing interests}

The authors declare that they have no competing interests.

\section{Authors' contributions}

DRM-Carried out the molecular genetic studies. Participated in the drafted the manuscript. STR - Performed the statistics and participated in the drafted the manuscript. NV- Responsible for cell cultures. CBP- Responsible for cell cultures. CM- Responsible for flow cytometry studies. CM- Participated in the molecular genetic studies. ND- Participated in the molecular genetic studies. IAS- Responsible for technical support of equipments used in the experiments. MS- Intellectual supervision. KRML- Responsible for the design of the study.

Supervision of the molecular assays and drafted of the manuscript. All authors read and approved the final manuscript.

\section{Acknowledgments}

This study was supported by FAPESP (10/51207-6).

Received: 26 February 2014 Accepted: 30 October 2014

Published online: 26 November 2014

\section{References}

1. Bartel DP: MicroRNAs: Target Recognition and Regulatory Functions. Cell 2009, 136(2):215-233.

2. Griffiths-Jones S, Grocock RJ, van Dongen S, Bateman A, Enright AJ: miRBase: microRNA sequences, targets and gene nomenclature. Nucleic Acids Res 2006, 34:D140-D144.

3. Friedman $\mathrm{RC}$, Farh $\mathrm{KKH}$, Burge $\mathrm{CB}$, Bartel DP: Most mammalian mRNAs are conserved targets of microRNAs. Genome Res 2009, 19(1):92-105.

4. Esteller M: Non-coding RNAs in human disease. Nat Rev Genet 2011 12(12):861-874.

5. Nelson Dip STR, Timoszczuk LS, Daniel Kanda A, Marcos D'O, Miguel S, Katia RM L: Under-expression of miR-100 may be a new Carcinogenic pathway for low-grade pTa Bladder Urothelial Carcinomas. J Mol Biomarkers Diagnosis 2012, 3(1):1-3. 
6. Wong TS, Liu XB, Wong BYH, Ng RWM, Yuen APW, Wei WI: Mature miR-184 as potential oncogenic microRNA of squamous cell carcinoma of tongue. Clin Cancer Res 2008, 14(9):2588-2592.

7. Henson BJ, Bhattacharjee S, O'Dee DM, Feingold E, Gollin SM: Decreased Expression of miR-125b and miR-100 in Oral Cancer Cells Contributes to Malignancy. Genes Chromosomes \& Cancer 2009, 48(7):569-582.

8. Shi W, Alajez NM, Bastianutto C, Hui ABY, Mocanu JD, Ito E, Busson P, Lo KW, Ng R, Waldron J, O'Sullivan B, Liu FF: Significance of PIk1 regulation by miR-100 in human nasopharyngeal cancer. Int J Cancer 2010, 126(9):2036-2048.

9. Petrelli A, Perra A, Schernhuber K, Cargnelutti M, Salvi A, Migliore C, Ghiso E, Benetti A, Barlati S, Ledda-Columbano GM, Portolani N, De Petro G, Columbano A, Giordano S: Sequential analysis of multistage hepatocarcinogenesis reveals that miR-100 and PLK1 dysregulation is an early event maintained along tumor progression. Oncogene 2012, 31(42):4517-4526.

10. Cairo S, Wang YP, de Reynies A, Duroure K, Dahan J, Redon MJ, Fabre M, McClelland M, Wang XW, Croce CM, Buendia MA: Stem cell-like micro-RNA signature driven by Myc in aggressive liver cancer. $P$ Natl Acad Sci USA 2010, 107(47):20471-20476.

11. Nam EJ, Yoon HJ, Kim SW, Kim HG, Kim YT, Kim JH, Kim JW, Kim SH: MicroRNA expression profiles in serous ovarian carcinoma. Clin Cancer Res 2008, 14(9):2690-2695.

12. Liu W, Gong YH, Chao TF, Peng XZ, Yuan JG, Ma ZY, Jia G, Zhao JZ: Identiflcation of differentially expressed microRNAs by microarray: a possible role for microRNAs gene in medulloblastomas. Chin Med J 2009, 122(20):2405-2411.

13. Ueda T, Volinia S, Okumura H, Shimizu M, Taccioli C, Rossi S, Alder H, Liu CG, Oue N, Yasui W, Yoshida K, Sasaki H, Nomura S, Seto Y, Kaminishi M, Calin GA, Croce CM: Relation between microRNA expression and progression and prognosis of gastric cancer: a microRNA expression analysis. Lancet Oncol 2010, 11(2):136-146.

14. Lee EJ, Gusev Y, Jiang JM, Nuovo GJ, Lerner MR, Frankel WL, Morgan DL, Postier RG, Brackett DJ, Schmittgen TD: Expression profiling identifies microRNA signature in pancreatic cancer. Int J Cancer 2007, 120(5):1046-1054.

15. Leite KR, Tomiyama A, Reis ST, Sousa-Canavez JM, Sanudo A, Dall'Oglio MF Camara-Lopes LH, Srougi M: MicroRNA-100 expression is independently related to biochemical recurrence of prostate cancer. J Urol 2011, 185(3):1118-1122.

16. Dip N, Reis ST, Timoszczuk LS, Viana NI, Piantino CB, Morais DR, Moura CM, Abe DK, Silva IA, Srougi M, Dall'Oglio MF, Leite KR: Stage, grade and behavior of bladder urothelial carcinoma defined by the microRNA expression profile. J Urol 2012, 188(5):1951-1956.

17. Song T, Xia W, Shao N, Zhang X, Wang C, Wu Y, Dong J, Cai W, Li H: Differential miRNA expression profiles in bladder urothelial carcinomas. APJCP 2010, 11(4):905-911.

18. Catto JW, Miah S, Owen HC, Bryant H, Myers K, Dudziec E, Larre S, Milo M, Rehman I, Rosario DJ, Di Martino E, Knowles MA, Meuth M, Harris AL, Hamdy FC: Distinct microRNA alterations characterize high- and low-grade bladder cancer. Cancer Res 2009, 69(21):8472-8481.

19. Rieger-Christ KM, Mourtzinos A, Lee PJ, Zagha RM, Cain J, Silverman M Libertino JA, Summerhayes IC: Identification of fibroblast growth factor receptor 3 mutations in urine sediment DNA samples complements cytology in bladder tumor detection. Cancer 2003, 98(4):737-744.

20. Neuzillet $Y$, Paoletti $X$, Ouerhani $S$, Mongiat-Artus $P$, Soliman $H$, de The $H$, Sibony M, Denoux Y, Molinie V, Herault A, Lepage ML, Maille P, Renou A, Vordos D, Abbou CC, Bakkar A, Asselain B, Kourda N, El Gaaied A, Leroy K, Laplanche A, Benhamou S, Lebret T, Allory Y, Radvanyi F: A Meta-Analysis of the Relationship between FGFR3 and TP53 Mutations in Bladder Cancer. Plos One 2012, 7(12):e48993.

21. Garcia JA, Danielpour D: Mammalian target of rapamycin inhibition as a therapeutic strategy in the management of urologic malignancies. Mol Cancer Ther 2008, 7(6):1347-1354.

22. Park SJ, Lee TJ, Chang $\mathrm{IH}$ : Role of the mTOR Pathway in the Progression and Recurrence of Bladder Cancer: An Immunohistochemical Tissue Microarray Study. Korean journal of urology 2011, 52(7):466-473.

23. Xu C, Zeng Q, Xu W, Jiao L, Chen Y, Zhang Z, Wu C, Jin T, Pan A, Wei R, Yang B, Sun Y: miRNA-100 Inhibits Human Bladder Urothelial Carcinogenesis by Directly Targeting mTOR. Mol Cancer Ther 2013, 12(2):207-219.

24. Lan L, Ui A, Nakajima S, Hatakeyama K, Hoshi M, Watanabe R, Janicki SM, Ogiwara H, Kohno T, Kanno S, Yasui UMA: The ACF1 complex is required for DNA double-strand break repair in human cells. Mol Cell 2010, 40(6):976-987
25. Havas K, Whitehouse I, Owen-Hughes T: ATP-dependent chromatin remodeling activities. Cell Mol Life Sci 2001, 58(5-6):673-682.

26. Mueller AC, Sun D, Dutta A: The miR-99 family regulates the DNA damage response through its target SNF2H. Oncogene 2013, 32(9):1164-1172.

27. Bessiere D, Lacroix C, Campagne S, Ecochard V, Guillet V, Mourey L, Lopez F, Czaplicki J, Demange P, Milon A, Girard JP, Gervais V: Structure-function analysis of the THAP zinc finger of THAP1, a large C2CH DNA-binding module linked to Rb/E2F pathways. J Bio/ Chem 2008, 283(7):4352-4363.

28. Macfarlan T, Kutney S, Altman B, Montross R, Yu J, Chakravarti D: Human THAP7 is a chromatin-associated, histone tail-binding protein that represses transcription via recruitment of HDAC3 and nuclear hormone receptor corepressor. The Journal of biological chemistry 2005, 280(8):7346-7358.

29. Roussigne M, Cayrol C, Clouaire T, Amalric F, Girard JP: THAP1 is a nuclear proapoptotic factor that links prostate-apoptosis-response-4 (Par-4) to PML nuclear bodies. Oncogene 2003, 22(16):2432-2442.

30. Cayrol C, Lacroix C, Mathe C, Ecochard V, Ceribelli M, Loreau E, Lazar V, Dessen P, Mantovani R, Aguilar L, Girardi JP: The THAP-zinc finger protein THAP1 regulates endothelial cell proliferation through modulation of pRB/E2F cell-cycle target genes. Blood 2007, 109(2):584-594.

31. Knowles MA: Molecular pathogenesis of bladder cancer. Int J Clin Oncol 2008, 13(4):287-297.

32. Zhou Y, Santoro R, Grummt I: The chromatin remodeling complex NoRC targets HDAC1 to the ribosomal gene promoter and represses RNA polymerase I transcription. The EMBO journal 2002, 21(17):4632-4640.

doi:10.1186/s12935-014-0119-3

Cite this article as: Morais et al:: The involvement of miR-100 in bladder urothelial carcinogenesis changing the expression levels of mRNA and proteins of genes related to cell proliferation, survival, apoptosis and chromosomal stability. Cancer Cell International 2014 14:119.

\section{Submit your next manuscript to BioMed Central and take full advantage of:}

- Convenient online submission

- Thorough peer review

- No space constraints or color figure charges

- Immediate publication on acceptance

- Inclusion in PubMed, CAS, Scopus and Google Scholar

- Research which is freely available for redistribution

Submit your manuscript at www.biomedcentral.com/submit
C) Biomed Central 